\title{
The trauma from the perspective of caregives of juvenile victims of family violence
}

\author{
Maiara Pereira Cunha ${ }^{1}$, Lucienne Martins Borges ${ }^{1}$
}

DOI: http://dx.doi.org/10.7322/jhgd.113786

\begin{abstract}
Introduction: A child exposed to violent events may go on to develop mental health problems such as post-traumatic stress disorder (PTSD). One of the stressful events that can cause PTSD is family violence.

Objectives: To describe traumatic events, and to identify the frequency of PSTD and the symptoms in juvenile victims of violence from the perspective of their mothers and caregivers.

Methods: The Affective Disorders and Schizophrenia for School Aged-Children Present and Lifetime Version (K-SADS-PL) clinical interview was used with the caregivers and children and semi-structured interviews were conducted only with the caregivers. The data from the K-SADS-PL clinical interview were organised in Microsoft Excel. For the analysis of the semi-structured interview data, Atlas/Ti 5.0 software was used.

Results: In total, 20 subjects participated, including 10 children between six and twelve years of age and 10 caregivers. The family composition that predominated was blended and the type of violence was psychological. Of the 10 children who participated in the survey, three were diagnosed with PTSD and four of them showed symptoms, but did not meet all the diagnostic criteria for the disorder. The most common traumatic events experienced by the children were physical abuse, witnessing domestic violence and experiencing trauma. It was found in the semi-structured interviews that trauma, from the perspective of the caregivers, was caused by losses and violence to which the children were exposed.

Conclusion: These findings suggest that it is urgent to think of strategies to prevent violence and to perform additional research on PTSD and violence in mental health services.
\end{abstract}

Keywords: family violence, childhood, post-traumatic stress disorder.

\section{INTRODUCTION}

Childhood is a period marked by motor, cognitive, affective and social development. The child, in turn, should be able to invest their energy in games and learning, free from the worries of the adult world. However, this is not always possible, since complications, such as family violence, can plague this phase and leave an indelible mark. It is worth mentioning that the developing child is in constant interaction with the environment and has moments of advances, transitions and regressions ${ }^{1}$. In the period of transition, it is possible that the child may be exposed to risky situations and, depending on the individual and contextual characteristics, present with mental health disorders, such as post-traumatic stress disorder (PTSD).
PTSD is characterised by the American Psychiatric Association (APA) ${ }^{2}$ as a clinical case belonging to the category of trauma-related disorders and stressors. The person must have been exposed to an extreme traumatic event, i.e. either witnessed or experienced the event. The event may have occurred with a relative or close friend, and may be revived persistently in one or more situations through memories, thoughts, perceptions and/or dreams. When exposed to something that refers to aspects of the traumatic situation, the person can act as if the traumatic situation is occurring again, accompanied by psychological suffering and/or a physiological reaction.

In addition to the symptoms described above, the person constantly dodges stimuli that refer to the event,

1 Maiara Pereira Cunha - Doutoranda em Psicologia pelo Programa de Pós Graduação em Psicologia pela Universidade Federal de Santa Catarina (UFSC).

2 Lucienne Martins Borges - Professora do Programa de Pós Graduação em Psicologia pela Universidade Federal de Santa Catarina (UFSC).

Corresponding author: Maria Pereira Cunha - Email: maiara_pereira@yahoo.com.br

Suggested citation: Cunha MP, Martins-Borges L. The Trauma from the perspective of mothers of juvenile victims of family violence. J Hum Growth Dev. 26(1): 101-111. DOI: http://dx.doi.org/10.7322/jhgd.113786

Manuscript submitted: Jan 28 2016, accepted for publication Feb 212016. 
which may lead to general numbness or increased excitability that were not present before the trauma. The symptoms need to be present for more than one month, and the subject must demonstrate suffering in their occupational and social spheres, as indicated by the $\mathrm{DSM}^{2}$. The disturbance does not occur due to physiological effects arising from for example, medicines, alcohol, or other medical conditions.

One of the events that can cause PTSD is violence. Violence is defined as intentional use of physical force or power against a person or a group, and the consequences of that relationship may include death, harm, deprivation and/or psychological suffering ${ }^{3}$. Violence committed against children and adolescents in Brazil is monitored by the Grievances and Notifications Information System (GNIS/SISAN). In 2011, it was found that female children were the most affected by violence, and the main place where this occurred was in the victim's residence. With respect to the type of violence, it was found that $40.5 \%$ of cases experienced physical violence, $20 \%$ sexual violence, $17 \%$ psychological violence and $16 \%$ negligence ${ }^{4}$.

In Brazil, the prevalence of PTSD in childhood is approximately 6.5\%, and at that frequency, psychological and social damage will affect both the victims and their families ${ }^{2}$. In this sense, Cunha and Malik-Borges ${ }^{5}$ indicated the importance of professionals sensitised to the problem of PTSD, as well as making support and psychological care available soon after the traumatic event or the appearance of the first symptoms, in addition to being able to perform proper diagnostics.

Thus, the objective of this study was to describe the traumatic events, identify the frequency of PTSD and symptoms found in children who are victims of violence from the perspective of mothers and stepmothers.

\section{METHODS}

The present research, of an exploratory and transverse nature, with predominantly qualitative measures, was carried out at the Psychosocial Attention Centre for the Child (PACC/CAPSi) which, since 2000, assists children who present with psychological problems.

A total of 20 participants took part in this research: 10 mothers or guardians and 10 children between six and twelve years of age. Participants were selected according to the following inclusion criteria: (1) had entered the children's mental health service between 2010 and 2013; (2) a minimum of six and maximum of twelve years of age to join the children's mental health service; (3) have been victims of some kind of family violence, whether it be physical, psychological, sexual and/or neglect, at least one month after the event; (4) attended the children's mental health service at the time of the study and (5) the parents or guardians have knowledge of the traumatic event experienced by the child. It is worth noting that the criterion relating to age is based on the Statute of the Child and Adolescent, in which a child is any person up to twelve years of age ${ }^{6}$. Favourable opinion: on 301,464.

\section{Data collection instruments}

Depending on the goals, a semi-structured interview was applied in order to access information and offer to mothers or stepmothers a chance to talk about the situations experienced by the children, on the basis of the following questions: a) to discuss the traumatic event experienced by the child; and b) to check if there had been modifications to the behaviour of the child.

To investigate the symptoms of PTSD, the clinical interview Affective Disorders and Schizophrenia for School-Aged Children Present and Lifetime Version (K-SADS-PL) was used with their mothers or guardians and with the children. The K-SADS-PL was drafted by Kaufman et al. ${ }^{7}$. Is a clinical interview that should be carried out with the parents or guardians and/or with children. Based on the diagnostic criteria of DSM-III/R (1987) and DSM-IV (1994), it seeks to identify disorders in childhood and adolescence. In Brazil, Bordin and Brasil $^{8}$ validated the instrument. The authors translated the English version into Portuguese (back-translation), assessed its content validity, construct validity and convergence. In addition, the reliability between evaluators and the test-retest score were evaluated in a sample of 78 children and their respective guardians who sought care at a mental health clinic for children.

In the application of this test in a clinical interview, it must be completed; this means that even is the researcher has interest only in the section corresponding to PTSD, the full test that investigates all the abovementioned disorders must be done. With respect to the section on PTSD, it consists of structured questions, which can be shown to the respondent to read them, or the researcher can interpret the question in their own words. In cases of the presence of symptoms of PTSD in the current diagnostic, the information must be entered as a current episode (CE). Otherwise, if there is a history of symptoms, but the participants have not experienced them for at least two months, the information will refer to a more serious episode that occurred in the past (MSEP). At the end of the instrument, and on the basis of the responses, it will be up to the researcher to assess the criteria in the DSM-IV (1994) regarding evidence of PTSD in children.

\section{Analysis of the data}

The interviews were fully transcribed and organised with Atlas/Ti 5.0 software, which enabled the construction of the analysis categories ${ }^{9}$. To calculate the frequencies and percentages of the K-SADS-PL clinical interview, the descriptive analysis of the data was performed in Microsoft Excel.

\section{RESULTS AND DISCUSSIONS}

\section{Participants' characteristics}

Table 1 presents the demographic information of the participants, such as age, education, the complaint that prompted the referral of the child to the service, diagnostic hypothesis upon admission of the child into mental health care, family composition and the type of violence suffered. (Table 1). 
Table 1: Participant's characterization

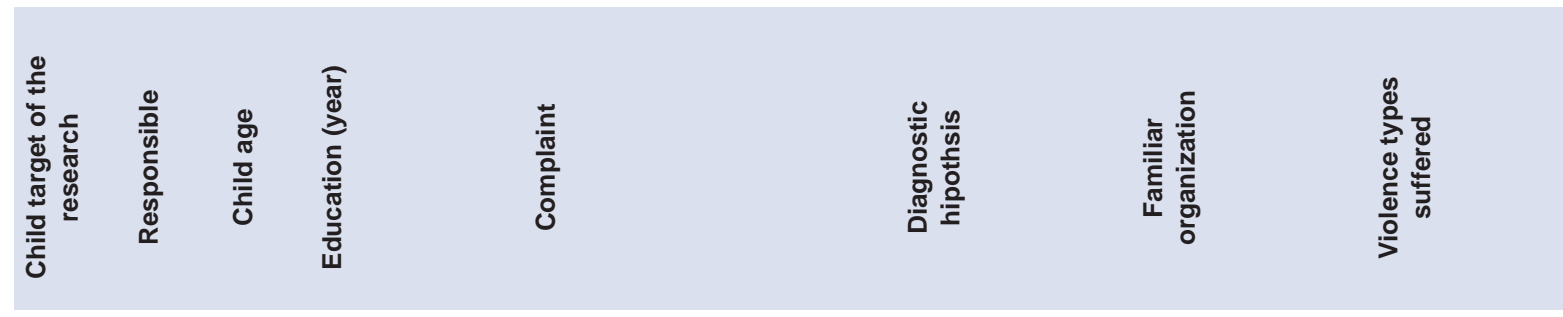

\begin{tabular}{|c|c|c|c|c|c|c|c|}
\hline $\begin{array}{c}\text { MA } \\
1\end{array}$ & R 1 & 8 & $3^{\circ}$ & Traumatic event & Acute stress reaction & Mono parental & Psychological \\
\hline $\begin{array}{c}\mathrm{MO} \\
2\end{array}$ & R 2 & 7 & $3^{\circ}$ & Aggressiveness & $\begin{array}{l}\text { Behavioural and } \\
\text { emotional disorders not } \\
\text { otherwise specified, with } \\
\text { onset usually in childhood } \\
\text { or adolescence }\end{array}$ & Compost & $\begin{array}{l}\text { Psychological; } \\
\text { Sexual; } \\
\text { Negligence }\end{array}$ \\
\hline $\begin{array}{c}\mathrm{MO} \\
3\end{array}$ & R 3 & 10 & $5^{\circ}$ & Aggressiveness & $\begin{array}{l}\text { Bipolar disorder or } \\
\text { depressive episodes }\end{array}$ & Compost & $\begin{array}{l}\text { Physical; } \\
\text { Psychological; } \\
\text { Negligence }\end{array}$ \\
\hline $\begin{array}{c}\mathrm{MO} \\
4\end{array}$ & R 4 & 8 & $4^{\circ}$ & Aggressiveness & $\begin{array}{l}\text { Hyperkinetic } \\
\text { disorders }\end{array}$ & Mono parental & $\begin{array}{c}\text { Physical; } \\
\text { Psychological }\end{array}$ \\
\hline $\begin{array}{c}\mathrm{MO} \\
5\end{array}$ & R 5 & 8 & $4^{\circ}$ & Aggressiveness & $\begin{array}{l}\text { Conduct disorder } \\
\text { unspecified }\end{array}$ & Compost & $\begin{array}{c}\text { Physical; } \\
\text { Psychological }\end{array}$ \\
\hline $\begin{array}{c}\text { MO } \\
6\end{array}$ & R 6 & 7 & $3^{\circ}$ & Agitation & $\begin{array}{l}\text { Anxiety disorder } \\
\text { unspecified }\end{array}$ & Extended & Psychological \\
\hline $\begin{array}{c}\text { MO } \\
7\end{array}$ & R 7 & 11 & $6^{\circ}$ & $\begin{array}{l}\text { Inadequate social } \\
\text { behavior }\end{array}$ & $\begin{array}{c}\text { Disorders of } \\
\text { psychological } \\
\text { development unspecified }\end{array}$ & Compost & Psychological \\
\hline $\begin{array}{c}\mathrm{MO} \\
8\end{array}$ & R 8 & 6 & $1^{\circ}$ & Mouring & $\begin{array}{l}\text { Anxiety disorder } \\
\text { unspecified }\end{array}$ & Extended & Psychological \\
\hline $\begin{array}{c}\text { MO } \\
9\end{array}$ & R 9 & 10 & $4^{\circ}$ & Aggressiveness & $\begin{array}{l}\text { Pervasive developmental } \\
\text { disorders }\end{array}$ & Compost & $\begin{array}{c}\text { Physical; } \\
\text { Psychological; } \\
\text { Negligence }\end{array}$ \\
\hline $\begin{array}{l}\text { MO } \\
10\end{array}$ & R 10 & 12 & $7^{\circ}$ & Aggressiveness & $\begin{array}{l}\text { Defiant and } \\
\text { oppositional disorder }\end{array}$ & Extended & Psychological \\
\hline
\end{tabular}

Note: Table elaborated by the authors of this article. 
In Table 1, the complaint is the reason why the child was transferred to the service, while the traumatic event refers to situations where the child's routine was affected by exposure to scenes of physical and psychological violence between the father and the mother, accompanied by intense fear and horror on the part of the child. Aggressiveness includes verbal and physical aggression directed toward peers (other children) and authority figures (parents and teachers). The agitation category relates to certain behaviours, both motor and verbal. The complaint agitation refers to intense verbal and motor behaviours. The complaint inappropriate social behaviour is related to situations in which the child lies and steals objects. The complaint mourning is related to the loss of a significant person to the child. Finally, the complaint withdrawn behaviour refers to children who are timid or socially isolated at school.

The diagnostic hypothesis of this study was recorded according to the ICD- $10^{10}$, which is the classification used in the records of the service. With respect to the diagnostic hypothesis, four participants arrived at reception with indications of emotional and behavioural disorders with onset usually occurring in childhood and adolescence. The most common disorders observed were anxiety or mood disorders. The same occurred in a study by Hoffmann, Saints and Mota ${ }^{11}$ which looked at the records of seven CAPSi sites, including emotional and behavioural disorders with onset usually occurring in childhood and adolescence; these disorders were observed in $44.5 \%$ ( $n=648$ ) of users. Delvan et al. ${ }^{12}$, published in 2010 the characterisation of the user profile and noted that 146 users were referred as a result of mental health problems, such as learning disorders, aggression, problems in relationships, or additional conditions that could be the focus of clinical attention.

In view of the predominance of males, Delfini, Dombi-Barbosa, Fonseca Tavares and Reis ${ }^{13}$ investigated 63 Records Centres (CAPSi) in the greater São Paulo and found that $25.4 \%(n=16)$ of boys had emotional and behavioural disorders, with onset usually occurring in childhood and adolescence. In female subject, 27.5\% $(n=11)$ of records did not include information on the diagnostic hypothesis.
According to Pedrini, Frizzo ${ }^{14}$, males often have outsourced behaviours, which are characterised by intrusive behaviours in the environment such as breaking the rules and aggressive behaviour. In turn, females tend to demonstrate internalised behaviours, i.e. behaviours linked to depression, withdrawal and anxiety. Thus, it was observed that the present research agrees with previous data on the male predominance in the mental health service. This information demonstrates that not only boys present distress, but also girls. However, as girls tend not to outsource their behaviour, they are taken less frequently to the mental health service. Boys, predominantly due to outsourced behaviours, are directed to mental health service more often than girls.

It is worth mentioning that information about the complaints and diagnostic hypotheses found in the CAPSi were obtained from the records of the interviews. Therefore, it is assumed that the diagnosis has been defined at the time the child began attending and, in many cases, lasted throughout the treatment period. According to Hoffmann et al. ${ }^{11}$, CAPSi tend to disregard comorbidities and possible changes in psychopathological cases, whose information records would be relevant.

The terminology used in the family composition was considered based on the document of the United Nations $^{15}$ and mentions that a residence consisting of a single-parent family is composed of a parent, either the father or the mother, and their children. It is possible to have a home with extended family, where the nuclear family (parents and children) reside with other relatives such as grandparents, uncles, cousins, etc. Finally, a compound residence is characterised by the presence of a parent (father or mother), companion (stepmother or stepfather) and their respective children. It is noteworthy that, in this study, the family composition excelled with five participants.

\section{Clinical Interview K-SADS-PL}

Table 2 was drafted with the aim to indicate the presence of the diagnosis and symptoms of PTSD in the participants. (Table 2).

Table 2: Presence or absence of current or past Post Traumatic Stress Disorder Post Traumatic diagnosis.

\begin{tabular}{|c|c|c|c|}
\hline $\begin{array}{l}\text { Child target of } \\
\text { the research }\end{array}$ & PSTD presence & Diagnosis criteria of current PSTD & Diagnosis criteria of past PSTD \\
\hline MA1 & NO & - It lacked an item of the criterion C & $\begin{array}{l}\text { - It lacked an item of the criterion C } \\
\text { - It lacked an item of the criterion D }\end{array}$ \\
\hline MA2 & YES & - Current PSTD evidence & - Past PSTD evidence \\
\hline MO3 & NO & - Instrument was not positive in the past & $\begin{array}{l}\text { - It lacked an item of the criterion B } \\
\text { - It lacked an item of the criterion C }\end{array}$ \\
\hline $\mathrm{MO} 4$ & NO & - Instrument was not positive in the past & - Instrument was not positive in the past \\
\hline MO5 & NO & - It lacked three items of the criterion C & - It lacked an item of the criterion C \\
\hline MO6 & NO & - It lacked two items of the criterion C & $\begin{array}{l}\text { - It lacked an item of the criterion C } \\
\text { - It lacked an item of the criterion D }\end{array}$ \\
\hline MO7 & NO & - Instrument was not positive currently & $\begin{array}{l}\text { - It lacked an item of the criterion B } \\
\text { - It lacked an item of the criterion C }\end{array}$ \\
\hline MO8 & NO & $\begin{array}{l}\text { - It lacked two items of the criterion C } \\
\text { - It lacked an item of the criterion D }\end{array}$ & - It lacked two items of the criterion C \\
\hline MO9 & YES & $\begin{array}{l}\text { - It lacked an item of the criterion B } \\
\text { - It lacked an item of the criterion D }\end{array}$ & - Past PSTD evidence \\
\hline MO10 & YES & - Current PSTD evidence & - Instrument was not positive in the past \\
\hline
\end{tabular}

Note: Table elaborated by the authors of this article. 
In this study, 30\% $(n=3)$ of participants showed evidence of current or past PTSD (MA2, MO9 and MO10). It is noteworthy that these participants also demonstrated the criteria of duration and suffering significant or functional impairment. With participants MO3 MO4, and MO7, the instrument was not positive for this determination. This indicates that, according to the clinical interview, the investigated traumatic events did not cause harm to these children. The same occurred in the past for MO4 and MO10. With the other participants, i.e. MA1, MO5, MO6 and M08, it was noted that they did not have all necessary diagnostic criteria for the presence of symptoms of criteria B (revival), C (persistent avoidance) and D (pronounced excitability).

Specifically with participants who have PTSD, a predominance of males was observed, with an average age of 9.6 years and average schooling of 4.6 years. The children were taken to the service with com- plaints of withdrawn behaviour $(\mathrm{n}=2)$ and aggression $(n=1)$; two of them were exposed to three types of violence and one to one type of violence. With respect to the family composition, the most frequent type was compound, while the third participant was from an extended family. The data from this study corroborate with the information of Graham-Bermann et al. ${ }^{16}$ and Ximenes et al. ${ }^{17}$, who mentioned that the accumulation of traumatic situations acts like a facilitator factor for the development of PTSD. Regarding the familial setting, Poletto and Koller ${ }^{18}$ stated that the family can be understood as a risk factor and/or protection, depending on the quality of the relationship between those involved, as well as the communication between the members and the context in which it is located.

Table 3 presents the traumatic events and the symptoms most often experienced by the participants of this study. (Table 3).

\section{Table 3: Traumatic events experienced by children through clinical interview K-SADSP-PL}

Traumatic events

Physical abuse

Domestic violence testimony

Traumatic news

Disaster testimony

Others

Other accidents

Fire

Car accidents

Violent transgression testimony

Sexual abuse

Diagnose criteria

Criterion B - Revival

Recurring, intrusive and distressing memories of the event, including images, thoughts or perceptions

Distressing dreams of the event

Acting or feeling as if the traumatic event were recurring

Intense distressing feeling due to exposure to stimuli that resemble or symbolize aspects of trauma

Physiological reactivity to stimuli

Criterion C - Persistent Avoidance

Avoid thoughts, feelings or conversations associated with the trauma

Avoid activities, places or people who do remember the trauma

Inability to remember important aspects of the trauma

Diminished interest or participation in significant activities

Detachment feeling or emotional shutdown

Inability to feel emotions

Limited future feeling

Criterion D - Increased Excitability

Insomnia

Irritability

Difficulty concentrating

Hypervigilance

Exaggerated startle response

\section{Frequency (\%)}

$70 \%(7)$

$70 \%(7)$

$60 \%(6)$

$50 \%$ (5)

$40 \%$ (4)

$30 \%$ (3)

$10 \%(1)$

$10 \%$ (1)

$10 \%(1)$

$10 \%(1)$

CE MSP

$40 \%$ (4)

(\%)

$50 \%$ (5)

$20 \%$ (2)

$10 \%(1)$

$20 \%$ (2)

$30 \%$ (3)

$20 \%$ (2)

20\% (2)

CE MSEP

(\%) (\%)

40\% (4) $\quad 50 \%(5)$

$20 \%(2) \quad 10 \%(1)$

$20 \%(2) \quad 50 \%(5)$

30\% (3) $\quad 30 \%$ (3)

$10 \%(1) \quad 10 \%(1)$

$10 \%(1)$

CE MSEP

(\%) (\%)

$30 \%$ (3)

$10 \%$ (1)

$20 \%(2)$

$40 \%$ (4)

$40 \%$ (4)

$20 \%$ (2)

$70 \%(7)$

$30 \%$ (3) $\quad 30 \%(3)$

Note: Table elaborated by the authors of this article. CE = Current Episode/ MSEP = most serious episode occurred in the past.

\section{Semi-structured interview}

Figure 1 shows the categories and subcategories and the elements of analysis that informed the results and discussion of the data, which will be described. (Figure 1).

In category 1 - Traumatic event, from the perspective of the participant, it was sought to understand this category based on reports of events experienced by the children. To this end, two subcategories were analysed: losses suffered by children and violence against children by family members. In subcategory 1.1 , losses suffered by children were identified on the basis of the perspective of mothers and stepmothers. In subcategory 1.1.1, abandonment was cited by four guardians as a traumatic event. 
CATEGORIES

CATEGORY 1
THE TRAUMATIC EVENT FROM THE PERS-
PECTIVE OF THE PARTICIPANT
CATEGORY 2
RESULTING SYMPTOMS OF TRAUMATIC
EVENT FROM THE PERSPECTIVE OF THE
GUARDIAN

\section{SUBCATEGORIES}

1.1 Losses suffered by children

\section{ANALYSIS ELEMENTS}

1.1.1 abandonment

1.1.2 family rejection

1.1.3 death of a significant other

1.1.4 separation from the mother

1.2.1 psychological violence

1.2 Violence against children by family 1.2 .2 negligence

1.2.3 physical violence

1.2.4 sexual violence

2.1.1 sadness

2.1 Psychiatric symptoms present in chil- 2.1 .2 anxiety

2.1.3 irritability

2.1.4 somatic symptoms

2.2 Behavioural symptoms present in 2.2.1 limitlessness

2.2.2 regressed behaviours

2.2.3 aggressiveness

2.3.1 poor school performance

Figure 1: Overviews of categories, subcategories and analysis elements

I abandoned everything when I met (referred to the name of the current companion) and did not look back. I grabbed my things and said goodbye (R3).

Based on the narratives, it was found that the traumatic event, from the perspective of the guardians, was related to abandonment. The life history of these children showed negligence throughout childhood that culminated in abandonment on the part of those responsible. It was concluded that the abandonment situation faced by children was linked to trauma, due to the presence of the element of surprise and despair, evidenced by MO9 and MO3. ${ }^{19}$

Another kind of loss, 1.1.2 family rejection, was reported by four participants:

My dad fights with my grandmother when I go there, because I am there. Over and over and over again he (referring to child) called me to talk: "Why doesn't Daddy like me? Did I do something to him? Why doesn't Daddy want to see me? Why doesn't he come to visit me? Why doesn't he come and get me? Why won't he talk to me when I go see Grandma?" It was so complicated. After that, his father didn't want contact with us, it's gone. There was a worse phase, because before there were fights they had their good moments, but from that moment on his father was gone. Finally, after we separated, his father went a long time without seeing him again.” (R6).

Tinoco and Franco ${ }^{20}$ mentioned that successive losses, as alluded to by R6, tend to destabilise the emotional development of the child. In addition, an aggravation is the child not having someone who assumes their care and welcomes their questions and emotions. Despite these circumstances, MO6 possessed a support network that may have taken on a protective function. Thus, the impact of the traumatic event does not seem to have com- promised the overall development of the child, as for example, proper school performance.

Yet, in the same subcategory, the analysis element 1.1.3: death of a significant other, was cited by three guardians:

MO7 cried a lot because of the death of his uncle who passed away. When he remembers, he cries, talks, but nowadays no longer speaks. I forgot how, but last year he remembered him enough. [...] When his uncle died, he was pretty scared. He is afraid to die. Because we took a scare at the time and MO7 witnessed that scare. I yelled a lot, my mother yelled a lot and I have not recovered. He was like a father to us (R7).

According to Franco and Mazorra ${ }^{21}$, the death of a significant person triggers a feeling of emotional and physical threat, which tends to mobilise the members of the family, as alluded to in the interview of R7. A family that experiences the impact of a loss usually presents difficulties in tackling this subject with children. Thus, the phase of development of the child, the type of death, the relationship of the family before and after the death, the way the family carried on after the death, i.e. whether the child was reassured about death and how it happens, become difficult or facilitators of mourning.

With regard to the traumatic event, in this case the death of a relative, Freud ${ }^{22}$ mentions that, for children, death does not bring the same feelings and values that are observed in adults. In a way, this infers that the impact of death on children is more connected to the way the family behaves before death rather than a direct experience with the same. Therefore, it is not the death of a loved one that characterises the traumatic event. The trauma observed here is related to psychological impacts, because of the suffering presented by family members and by changes in family dynamics. 
Finally, one participant mentioned 1.1.4: separation from the mother

They (referring to the paternal grandmother and father of the child) went to the school and sought her (the child). I (mother of the child) walked out of the Forum in a state of shock. The bailiff cried of despair. I do not remember everything. I remember the pain that I felt, that I grabbed her (referring to the daughter). I then hurt him (referring to the bailiff), and ended up with scratch marks from my daughter on my shoulder (R2).

In this case, the child lived with her mother, but for judicial enforcement due to the dispute between the parents, the child went to live with relatives in a different city. Therefore, she changed to a new school and had to adapt to new family members. The traumatic event in this excerpt is in the separation of mother and daughter, and the deprivation of a mother. Even returning to living with the mother, the child showed fear and horror with the possibility of being removed again. This example shows one of the criteria of PTSD, which is to live constantly with the feeling that the traumatic situation is about to happen again.

Subcategory 1.2 violence against children by family members describes the types of family violence to which the children were exposed, including psychological violence, neglect, physical violence and sexual violence. Seven participants made reference to 1.2.1: psychological violence

Had once when I won it (MO4's sister) and my mother (MO4), he I remember to this day that he (referring to the child's stepfather) grabbed me by the neck and said he was going to kill me. Then I started throwing up and he rubbed my face on the floor in the room and my mother (MO4) saw it. MO4 talked to many people about this (R4).

According to the Ministry of Health ${ }^{3}$, psychological violence includes acts of humiliation, depreciation and ridicule, as noted in the quote of $\mathrm{R} 4$, in that the child's mother is sentenced to death and undervalued by his companion. Even with R4, it was observed that the child was exposed to violence since his stepfather had assaulted his wife. In this case, the child was exposed directly and indirectly to violence. Durant et al. ${ }^{23}$, indicate that the suffering of the mother can have an impact on the children.

In the same subcategory, three participants reported 1.2.2: negligence

She (referring to the paternal grandmother) took my daughter to go out at night (referring to night parties). [...] R2 got pneumonia because her grandmother put her in sandals and a dress for a walk on the Boardwalk [...] (R2).

In the narrative of R2, negligence was characterised by the fact that the child be exposed to unsuitable situations for their age and development. This is aligned with Martins and Jorge ${ }^{24}$ who showed that the practices of neglect are often related to female figures.

The next element of analysis, 1.2.3: physical violence, was cited by three participants:

When he was little and still wet his pants, his father got angry and filled his underwear with worms and after that, did he wear underwear. MO5 cried a lot, a lot, and was forever afraid of putting on underwear [...] Once, MO5 did mess of child, and his father beat him using a strap with such force that he was full of brands of girdled (R5).

The quote of R5 shows that physical violence was characterised by the use of physical force, which involved hitting with straps and slippers. The narratives of the participants agree with Martins and Jorge ${ }^{24}$ and Waiselfisz ${ }^{4}$, who showed that the predominant type of family violence is physical violence.

The last element of the analysis subcategory violence, 1.2.4: sexual violence, appeared once:

...when her grandmother went out to work, the uncle called her to go to the bathroom and asked her to examine his penis, claiming that he was hurt. Her grandmother bought a nurse kit for her to play with the uncle, then she also played with the uncle's penis (R2).

In the case of R2, in addition to sexual violence, the child was exposed to neglect and psychological violence. As pointed out by the literature referring to this issue, the presence of various types of violence of concomitant form tends to be frequent, which can increase the vulnerability to PTSD.

With category 1, it appears that the narratives showed trauma through losses and the violence to which children were exposed and that led to psychological suffering. With regard to losses, it is assumed that the traumatic event is related to the breach of a significant link to the child. In the case of death, there seems to be a particularity, because the loss is not related to the loved one who died, but to the family structure. In relation to the subcategory violence, a predominance of psychological violence was observed, which to some extent contradicts the literature. This shows how the actions and behaviours of the participants are perceived as violence and many are transmitted among generations. With category 1 , the inter actuation of the types of violence and the presence of the traumatic event from the perspective of the participants was verified.

Category 2 - Symptoms resulting from the traumatic event from the perspective of the guardian investigated symptoms resulting from exposure to traumatic events, through the following sub-categories: psychological symptoms present in children, behavioural symptoms present in children, and cognitive symptoms present in children.

Subcategory 2.1 - psychological symptoms in children was mentioned, based on the participants' narratives. Five guardians alluded to subcategory 2.1.2: sorrow: 
In the past she (referring to daughter) cried like.... how can I tell you... a sentimental child, I couldn't say anything to her because she would cry. And now, it is a cry of sadness. I noticed that we see her crying in sorrow, due to something that she feels, that hurts her, something you know, is different $[\ldots](R 1)$

Note that R1 asserts that the present crying is due to sorrow, and therefore is different from previous situations. This is aligned with a study by Gava, Silva and Dell'Aglio ${ }^{25}$ which, after searching expert reports on children who were victims of violence, found that these children experienced the symptoms of depression, including sadness, a depressed mood and crying.

Four participants reported 2.1.2: anxiety:

The change that I perceived was a fear of dying, he (the child) had that trauma, a fear of dying. Every time, he thought he was going to die. I stayed with that and he did too. Do you understand me? (R7).

In the quote from R7, one senses the presence of symptoms of PTSD, as recurrent, intrusive and afflictive remembrances of the event, including images, thoughts or perceptions, due to reports of an intense fear of dying. The impact of the traumatic event in the mother can also impair the child.

Three guardians cited 2.2.3: irritability:

That is what I said to you (referring to the teacher), he became more agitated, [...], more rude, because he automatically isolated the family he had, he says no one is related to me. Do you understand? (R10).

Lopez-Soler et al. ${ }^{26}$, observed that children exposed to violence demonstrate aggressiveness, showing hostile behaviours, irritability as well as difficulties and inadequate control of aggressive strategies. Therefore, it is understandable that irritability can arise as a symptom to communicate situations of profound dissatisfaction. In the case of MO10, after obtaining knowledge of its biological origin, the child went on to express excitement and frustration with more intensity.

The last analysis element of the psychological symptoms subcategory, 2.1.4: somatic symptoms, was referred to by two participants:

I had already made some previous queries with the doctor about six months ago. There were some medical tests, and she had the same symptoms (chest pain, shortness of breath and pain in the belly). Then the doctor told me to do all the tests, and asked me to return. Then I returned and she said there was nothing in the tests. Six months later, I came back and said she was feeling the same symptoms. Then she said to me, her mother: there is nothing, there is nothing (R1).

As illustrated by R1, after traumatic events, children can present with somatic symptoms, such as chest pain, shortness of breath and pain in the belly. As pointed out by Marcelli and Cohen ${ }^{27}$, traumatic events can trigger anxiety, causing discomfort that can often be manifested in the body by means of somatic symptoms. The above reports are in line with the research of Kugler, Bloom, Kaercher, Truax and Storch ${ }^{28}$, who noted the presence of somatic symptoms in children who were victims of family violence.

With the subcategory 2.2 - Behavioural symptoms in children - participants reported the main behavioural symptoms.

Family have cited the analysis 2.2.1 lack of limits:

[...] behaving in a while here, this thing of not having limits, and does not respect anyone, not the teacher, or Grandma, or the mother, or the aunt, or anyone and will be very rude towards them, always wanting to have the last word, even if you don't have anything else to discuss and call you that, silly! (R6).

According to Maercelli and Cohen ${ }^{27}$, frustration intolerance is often characterised by the difficulty of the child in discerning the boundaries between the outside world and the inner world ${ }^{28}$. As well as irritability, the lack of limits seems to indicate vulnerability in relation to the outside world, a world that appears as an element that frustrates and threatens.

Two participants cited 2.2.2: regressed behaviours:

She (child) returned there, sucking, bedwetting, afraid of the dark, drinking from a bottle, she was not my girl (crying) (R2).

Regressed behaviours are seen as behaviours inconsistent with the developmental stage and the age of the child and which had already been acquired and integrated into previous steps of its development, as shown by R2. As pointed out by Graham-Bermann et al. ${ }^{16}$, children exposed to family violence tend to have regressed behaviours, which in turn interfere in the child's development.

One participant referred to 2.2.3: aggression

(Child's name) came to (mental health service) because he was aggressive with two children in high school. He hit two children. He said he would hit by anything, he said he wanted. Complicated! (R3).

The above narrative shows the difficulty of MO3 in dealing with conflict at school, which led to physical aggression. It is assumed that the violence experienced by MO3 at home has been reproduced in the school environment.

In the case of the aggressive acts presented here, they seem to denote a line of communication from bitter frustration. A child or an adult who does not work on their frustrations will express them through aggressive gestures, according to MartinsBorges et al. ${ }^{29}$. 
In subcategory 2.3 - cognitive symptoms in children, two guardians cited 2.3.1: poor performance in school

[...] The Director said to me: MO4 has failed this year. He got a 2, he got 0 . He refuses to do the activities. I (the child's mother) mentioned this to the psychiatrist last time [...] (R4).

Based on R4, difficulties related to the teaching-learning process as well as cognitive symptoms point to the impact of family violence in the school context. These data are in line with Preto and Moreira ${ }^{30}$, who compared school averages between the children of victims and non-victims; the former showed poorer performance in school. In addition, when the mothers of the children were exposed to physical and psychological violence, the children of victims demonstrated difficulties in the teaching-learning process.

In general, after traumatic events, children/participants showed various symptoms, which had an impact on their integral development. Such symptoms were not restricted to psychological manifestations, but also left a mark on behaviour and the learning process as elucidated by the participants.

It was found that the 10 children who participated in the research came to the services because of aggressiveness. At the time of the survey, the children lived mostly with their families. The most common type of violence mentioned in their reports and in the reports of their guardians was psychological.

In view of the objectives of this article, the most frequent traumatic events are physical abuse, witnessing domestic violence, traumatic news and hearing about a disaster. This last event is a regional feature given the history of flooding, because the region is recurrently devastated by floods. Regarding the identification of the frequency of post-traumatic stress disorder, $30 \%$ of the participants demonstrated all of the diagnostic criteria of PTSD.

Considering the symptoms, other children showed other symptoms and signs of suffering. With regard to symptoms that appeared often, criterion B - revival - appeared in $50 \%$ of cases in the past, with recurrent, intrusive remembrances of a grievous event, including images, thoughts and perceptions. In turn, criterion $\mathrm{C}$ - persistent avoidance - predominated. Avoiding thoughts, feelings or conversations associated with the trauma and decreased interest or participation in important activities, both with $50 \%$ for the past. With respect to criterion D - increased excitability $-70 \%$ of participants demonstrated the symptom of hypervigilance in the past.

Thus, it was found that, in addition to diagnosis, the situations of violence and the losses to which children were exposed also left marks. This infers that suffering was expressed by the participants of this research in different ways, both through the body, expressed in relationships that were controversial or even aggressive, and also affecting cognition and the learning process, as shown in reports of the participants of this research.

The semi-structured interview technique, essential to give voice to participants, allowed access to traumatic events - in the form of losses and violence - according to the perspective of those responsible. The reported losses were dropouts, rejection, death of a loved one and separation. Violence consisted of psychological violence, neglect, physical violence and sexual violence. It should be noted that the data of the interview dialogue was combined with the findings of the K-SADS-PL clinical interview.

After exposure to these traumatic events, the children presented psychological symptoms, cognitive and behavioural. Sadness, anxiety, irritability and somatic symptoms were named and psychological symptoms expressed by children or reported by their responsible. To characterise the behavioural symptoms, participants mentioned a lack of boundaries, regressive conduct and aggressiveness. The only cognitive symptom listed by participants was poor school performance.

With respect to the limitations of this study, it should be noted that the definition of childhood was made according to the Statute of the Child and Adolescent; the chronological age established for children differs from the criteria used by the United Nations.

\section{REFERENCES}

1. Marinho-Araujo CM. A ciência do desenvolvimento humano: para além de uma Psicologia do Desenvolvimento. Psicol Esc Educ. 2006;10(1):135-6. DOI: http://dx.doi.org/10.1590/S1413-85572006000100013

2. Associação de Psiquiatria Americana (APA). Manual diagnóstico e estatístico de transtornos mentais: DSM-5. Porto Alegre: Artmed; 2014.

3. Brasil. Ministério da Saúde. Violência intrafamiliar: orientações para a prática em serviço. Brasília: MS; 2002. [cited 2015 Aug 12] Available from: http://bvsms.saude.gov.br/bvs/publicacoes/cd05_19.pdf.

4. Waiselfisz JJ. Atendimento por violências no SUS. In: Waiselfisz JJ. Mapa da violência 2012: crianças e adolescentes do Brasil. Rio de Janeiro: FLACSO Brasil; 2012; p.62-73.

5. Cunha MP, Martins-Borges L. Transtorno de estresse pós-traumático (TEPT) na infância e adolescência e sua relação com a violência familiar. Bol Acad Paulista Psicol. 2013;33(85):312-29.

6. Brasil. Estatuto da Criança e do Adolescente: Lei 8.069/90, de 13 de Julho de 1990. Brasília: Senado Federal; 1990.

7. Kaufman J, Birmaher B, Brent D, Rao U, Flynn C, Moreci P, et al. Schedule for Affective Disorders and Schizophrenia for School-Aged Children Present and Lifetime Version (K-SADS-PL): initial reliability and validity data. J Am Acad Child Adolesc Psychiatry. 1997;36(7):980-8. DOI: http://dx.doi. org/10.1097/00004583-199707000-00021 
8. Brasil HH, Bordin Al. Convergent validity of K-SADS-PL by comparison with CBCL in a Portuguese speaking outpatient population. BMC Psychiatry. 2010;10:83. DOI: http://dx.doi.org/10.1186/1471-244X-10-83

9. Cantero DSM. Teoría fundamentada y Atlas.ti: recursos metodológicos para la investigación educativa. REDIE. 2014;16(1):104-22.

10. Organização Mundial da Saúde (OMS). Classificação de transtornos mentais e de comportamento da CID-10: descrições clínicas e diretrizes diagnósticas. Porto Alegre: Artmed; 1993.

11. Hoffmann MCCL, Santos ND, Mota ELA. Caracterização dos usuários e dos serviços prestados por Centros de Atenção Psicossocial infantil-juvenil. Cad Saúde Pública. 2008;24(3):633-42. DOI: http://dx.doi. org/10.1590/S0102-311X2008000300017

12. Delvan JS, Portes JRM, Cunha MP, Menezes M, Legal EJ. Crianças que utilizam os serviços de saúde mental: caracterização da população em uma cidade do Sul do Brasil. Rev Bras Desenvolvimento Hum. 2010;20(2):228-37.

13. Delfini PSS, Dombi-Barbosa C, Fonseca FL, Tavares CM, Reis AOA. Perfil dos usuários de um centro de atenção psicossocial infanto-juvenil da grande São Paulo, Brasil. Rev Bras Desenvolvimento Hum. 2009;19(2):226-36.

14. Pedrini JR, Frizzo GB. Avaliação de indicadores de problemas de comportamento infantil relatados por pais e professores. Aletheia. 2010;(33):223-33.

15. Organização das Nações Unidas (ONU). Principles and recommendations for population and housing censuses. New York: United Nations; 2008.

16. Graham-Bermann SA, Castor LE, Miller LE, Howell KH. The impact of intimate partner violence and additional traumatic events on trauma symptoms and PTSD in preschool-aged children. J Trauma Stress. 2012;25(4):393-400. DOI: http://dx.doi.org/10.1002/jts.21724

17. Ximenes LF, Oliveira RVC, Assis SG. Violência e transtorno de estresse pós traumático na infância. Ciênc Saúde Coletiva. 2009;14(2):417-33. DOI: tp://dx.doi.org/10.1590/S1413-81232009000200011

18. Poletto M, Koller SH. Contextos ecológicos: promotores de resiliência, fatores de risco e de proteção. Estud Psicol. 2008;25(3):405-16. DOI: http://dx.doi.org/10.1590/S0103-166X2008000300009

19. Meshulam-Werebe D, Andrade MGO, Delouya D. Transtorno de estresse pós-traumático: o enfoque psicanalítico. Rev Bras Psiquiatr. 2003;25(Suppl. 1):37-40. DOI: http://dx.doi.org/10.1590/S151644462003000500009

20. Tinoco V, Franco MHP. O luto em instituições de abrigamento de crianças. Estud Psicol. 2011;28(4):42734. DOI: http://dx.doi.org/10.1590/S0103-166X2011000400003

21. Franco MHP, Mazorra L. Criança e luto: vivências fantasmáticas diante da morte do genitor. Estud Psicol. 2007;24(4):503-11. DOI: http://dx.doi.org/10.1590/S0103-166X2007000400009

22. Freud S. Luto e melancolia. In: Freud S. Introdução ao narcisismo, ensaios e metapsicologia e outros textos. São Paulo: Companhia das letras; 1917; p.171-194.

23. Durant JG, Schraiber LB, França-Junior I, Barros C. Repercussão da exposição à violência por parceiro íntimo no comportamento dos filhos. Rev Saúde Pública. 2011;45(2):355-64. DOI: http://dx.doi. org/10.1590/S0034-89102011005000004

24. Martins CBG, Jorge MHPM. Violência física contra menores de 15 anos: estudo epidemiológico em cidade do sul do Brasil. Rev Bras Epidemiol. 2009;12(3):325-37. DOI: http://dx.doi.org/10.1590/S1415$-790 \times 2009000300004$

25. Gava LL, Silva DG, Dell'Aglio DD. Sintomas e quadros psicopatológicos identificados nas perícias em situações de abuso sexual infanto- juvenil. Psico. 2013; 44(2): 235-44.

26. López-Soler C, Fernández MV, Prieto M, Alcántara MPMV, Castro M, López-Pina JA. Prevalencia de las alteraciones emocionales en una muestra de menores maltratados. Anales Psicol. 2012;28(3):780-788. DOI: http://dx.doi.org/10.6018/analesps.28.3.140441

27. Marcelli D, Cohen D. Os transtornos de ansiedade, os sintomas e a organização de aparência neurótica. (Murad, Fátima. Trad.). In: Marcelli D. Manual de psicopatologia da infância de Ajuriaguerra. Porto Alegre: Artmed; 2010; p. 298-332.

28. Kugler BB, Bloom M, Kaercher LB, Truax TV, Storch EA. Somatic symptoms in traumatized children and adolescents. Child Psychiatry Hum Dev. 2012;43(5): 661-73. DOI: http://dx.doi.org/10.1007/s10578012-0289-y

29. Martins-Borges L, Mayorca DS, Livramento MS. Atendimento psicológico em situações de violência conjugal. In: MC Zurba. Psicologia e Saúde Coletiva. Florianópolis: Tribo da Ilha; 2011; p. ;157-168.

30. Preto M, Moreira PAS. Autoregulação da aprendizagem em crianças e adolescentes filhos de vítimas de violência doméstica contra mulheres. Psicol Reflex Crít. 2012;25(4):730-7. DOI: http://dx.doi.org/10.1590/ S0102-79722012000400012 
This article is distributed under the terms of the Creative Commons Attribution 4.0 International License (http://creativecommons.org/licenses/by/4.0/), which permits unrestricted use, distribution, and reproduction in any medium, provided you give appropriate credit to the original author(s) and the source, provide a link to the Creative Commons license, and indicate if changes were made. The Creative Commons Public Domain Dedication waiver (http://creativecommons.org/publicdomain/zero/1.0/) applies to the data made available in this article, unless otherwise stated.

\section{Resumo}

Introdução: A criança exposta a eventos de risco pode vir a desenvolver problemas de saúde mental, como, por exemplo, o Transtorno de Estresse Pós-Traumático (TEPT). Um dos eventos estressores que pode ocasionar o TEPT é a violência familiar.

Objetivos: Descrever os eventos traumáticos, identificar a frequência do Transtorno de Estresse Pós-Traumático e os sintomas encontrados em crianças vítimas de violência sob a perspectiva das mães e madrastas.

Método: Utilizou-se a entrevista clínica Affective Disorders and Schizophrenia for School Aged-Children and Lifetime Version (K-SADS-PL) com os responsáveis e com as crianças, sendo que a entrevista semiestruturada foi feita apenas com os responsáveis. Os dados extraídos da entrevista clínica K-SADS-PL foram organizados no Microsoft Excel, já para a análise dos dados da entrevista semiestruturada, utilizou-se o software Atlas/Ti 5.0.

Resultados: Participaram 20 sujeitos, 10 crianças entre seis e 12 anos de idade e 10 responsáveis. Predominou a composição familiar composta e o tipo de violência que sobressaiu foi a psicológica. Das 10 crianças que fizeram parte da pesquisa, três apresentaram diagnóstico de TEPT e quatro delas demonstraram sintomas, apesar de não fecharam todos os critérios de diagnósticos para o transtorno. Os eventos traumáticos mais frequentes vividos pelas crianças foram: abuso físico, testemunhar violência doméstica e receber notícias traumáticas. Constatou-se na entrevista semiestruturada o traumático, na percepção dos responsáveis, enquanto perdas e violências às quais as crianças foram expostas.

Conclusão: É premente problematizar e pensar em estratégias de prevenção à violência, assim como pesquisar sobre violência e TEPT nos serviços de saúde mental.

Palavras-chave: violência familiar, infância, transtorno de estresse pós-raumático. 